\title{
ANALISIS PENGGUNAAN BATU SERPIH SEBAGAI MEDIA PENYIMPAN PANAS PADA KOLEKTOR SURYA
}

\author{
Suhendra ${ }^{1}$, Feby Nopriandy ${ }^{2}$ \\ Jurusan Teknik Mesin, Politeknik Negeri Sambas ${ }^{1,2}$ \\ Jl. Raya Sejangkung Kawasan Pendidikan Tinggi Sambas, Tumuk Manggis, Kecamatan \\ Sambas, Kabupaten Sambas, Kalimantan Barat 79463, Indonesia \\ e-mail: aka.suhendra@yahoo.com¹, febynopriandy123@yahoo.com
}

\begin{abstract}
Abstrak
Pengeringan merupakan suatu proses yang bertujuan untuk pengawetan bahan pangan dengan cara mengurangi kadar air yang terkandung di dalam bahan tersebut menggunakan energi panas. Permasalahan pada pengering dengan sumber panas dari energi matahari adalah temperatur yang dihasilkan tidak stabil. Upaya mengatasi permasalahan stabilitas temperatur adalah merancang bangun kolektor surya yang dilengkapi media penyimpan panas. Tujuan penelitian yang dilakukan adalah membuktikan pengaruh media penyimpan panas berupa batu serpih dan pengaruh kecepatan aliran udara terhadap stabilitas temperatur yang dihasilkan kolektor surya pelat bergelombang. Pengujian pada kolektor surya dilakukan menggunakan media dan tanpa media penyimpan panas. Kecepatan aliran fluida yang keluar kolektor surya divariasikan menjadi 3 perlakuan yaitu $2 \mathrm{~m} / \mathrm{s}, 4 \mathrm{~m} / \mathrm{s}$ dan $6 \mathrm{~m} / \mathrm{s}$. Pengambilan data dimulai dari pukul 08.00 sampai pukul 16.00 WIB dengan selang waktu pengambilan data adalah setiap 30 menit. Hasil uji kinerja menunjukkan bahwa kolektor surya dengan tambahan media penyimpan panas berupa batu serpih dapat meningkatkan performansi kolektor sebesar 3,92\% pada ruang kolektor surya, dan sebesar 4,63\% pada saluran keluar kolektor surya. Temperatur pada ruang kolektor dan saluran keluar kolektor yang menggunakan media penyimpan panas lebih stabil pada saat terjadi penurunan radiasi matahari. Kecepatan aliran udara pada saluran keluar kolektor mempengaruhi temperatur dalam ruang dan saluran keluar kolektor surya. Semakin cepat aliran udara keluar dari saluran keluar kolektor maka temperatur udara panas dalam ruang dan saluran keluar kolektor surya semakin rendah. Hasil pengujian mendapatkan temperatur tertinggi dalam ruang dan saluran keluar kolektor masing-masing sebesar $48,05^{\circ} \mathrm{C}$ dan $49,93^{\circ} \mathrm{C}$ pada saat kecepatan aliran udara $2 \mathrm{~m} / \mathrm{s}$.
\end{abstract}

Kata kunci: Batu serpih, Kolektor surya, Media penyimpan panas.

\section{PENDAHULUAN}

Proses pengeringan produk pangan umumnya menggunakan sumber panas dari sinar matahari. Penggunaan panas matahari sangat menguntungkan karena ketersediaannya sangat melimpah dan mudah diperoleh sehingga memiliki potensi yang sangat besar. Energi matahari merupakan salah satu energi alternatif dengan pemanfaatan yang tinggi disebabkan ketersedianya di daerah tropis tak terbatas [1].

Teknik pengeringan yang banyak diaplikasikan oleh masyarakat adalah dengan menjemur produk pertanian langsung di bawah sinar matahari. Proses pengeringan dengan cara tersebut sangat bergantung pada kondisi cuaca, pengeringan berlangsung relatif lama, kebersihannya kurang terjaga, kualitas pengeringan relatif tidak seragam dan memerlukan tempat yang luas. Upaya untuk mengatasi kelemahan penjemuran langsung adalah dengan membuat pengering buatan yang sumber panasnya tetap menggunakan energi matahari.

Pengering dengan sumber panas yang berasal dari energi matahari memerlukan kolektor surya yang dapat menyerap dan 
menyimpan radiasi matahari serta merubahnya menjadi energi panas. Panas yang dihasilkan dapat digunakan untuk meningkatkan temperatur udara yang mengalir pada ruang pengering.

Permasalahan pada pengering dengan kolektor surya adalah temperatur yang dihasilkan oleh kolektor surya tidak stabil. Temperatur yang keluar dari kolektor surya dapat secara drastis naik atau turun secara tiba-tiba. Hal ini sangat tergantung dari kondisi cuaca pada saat proses pengeringan berlangsung. Temperatur yang terlalu tinggi atau terlalu rendah berpotensi merusak bahan yang dikeringkan sehingga dapat menurunkan kualitas bahan yang dikeringkan.

Berbagai penelitian telah dilakukan untuk mengatasi permasalahan temperatur pengeringan yang tidak stabil. Pengujian pengering menggunakan sumber panas energi matahari telah dilakukan dengan air sebagai media penyimpan panas [2], hasilnya menunjukkan bahwa kenaikan suhu air di bak sebesar $20^{\circ} \mathrm{C}$ terjadi selama 330 menit pemanasan dari suhu $30^{\circ} \mathrm{C}$ menjadi $50^{\circ} \mathrm{C}$ dengan radiasi matahari ratarata sebesar 527,29 $\mathrm{W} / \mathrm{m}^{2}$. Pengujian dengan sumber panas dari tungku biomassa menghasilkan kenaikan suhu sebesar $10,5^{\circ} \mathrm{C}$ terjadi selama 435 menit dari suhu $30^{\circ} \mathrm{C}$ menjadi $40,5^{\circ} \mathrm{C}$. Pengujian lain dilakukan dengan menambahkan media penyimpan panas berupa batu pada kolektor surya [3]. Hasil penelitian tersebut menunjukkan bahwa media penyimpan panas dapat menstabilkan temperatur udara panas ketika terjadi fluktuasi radiasi matahari. Temperatur udara maksimum yang keluar dari kolektor surya dapat diturunkan sebesar $12^{\circ} \mathrm{C}-18^{\circ} \mathrm{C}$. Penelitian lain menambahkan pasir sebagai media penyimpan panas pada kolektor surya pelat datar [4]. Hasil pengujian pada kolektor surya dengan media penyimpan panas saat radiasi matahari rendah menunjukkan terjadi peningkatan efisiensi sebesar 32,7\% dibanding kolektor surya tanpa media penyimpan panas yaitu sebesar 28,6\%. Penggunaan kendal sebagai media penyimpan panas pada kolektor surya pelat datar dapat menstabilkan suhu saat radiasi matahari sudah tidak ada [5].

Berdasarkan permasalahan tersebut, diperlukan upaya untuk mengatasi permasalahan stabilitas temperatur pada kolektor surya. Oleh karena itu, perlu dilakukan penelitian pada kolektor surya dengan menambahkan media penyimpan panas. Beberapa media yang umumnya digunakan sebagai media penyimpan panas seperti air, pasir dan batu. Hal lain yang perlu diupayakan untuk menstabilkan temperatur pengeringan adalah dengan melakukan pengaturan kecepatan aliran udara panas yang keluar dari kolektor surya.

Penelitian dilakukan dengan merancang kolektor surya yang dilengkapi media penyimpan panas serta mengatur kecepatan aliran udara panas yang keluar dari kolektor surya. Penambahan media penyimpan panas dan pengaturan kecepatan aliran udara panas diharapkan dapat menstabilkan temperatur udara panas pengeringan.

\section{TINJAUAN PUSTAKA}

Pengering yang memanfaatkan energi surya sebagai sumber energi panas disebut pengering tipe efek rumah kaca (ERK). ERK dihasilkan oleh penutup transparan pada alat pengering. Radiasi gelombang pendek matahari yang melewati penutup transparan sebagian diserap oleh plat absorber dan sebagian lagi dipantulkan. Pantulan ini membentuk gelombang panjang sehingga terperangkap dalam ruang perangkap panas. Akibat peristiwa ini suhu dalam perangkap panas akan mengalami peningkatan.

Perkembangan mengenai penelitian pengering efek rumah kaca telah banyak dilakukan dengan bentuk dan tipe yang bermacam-macam antara lain pengering efek rumah kaca dengan plat absorber dan rak sebagai wadah produk yang dikeringkan [6]. Pengering tipe efek rumah kaca tipe lain adalah pengering ERK hybrid berbentuk kerucut, pengering ERK hybrid 
tipe terowongan menggunakan energi surya dan energi biomassa, pengering ERK hybrid tipe kabinet, pengering ERK hybrid dengan wadah silinder berputar, pengering ERK hybrid tipe rak berputar. Beberapa modifikasi pada pengering untuk mendapatkan hasil yang optimal juga banyak dilakukan. Pengering ERK tipe rak untuk pengeringan kakao menggunakan absorber dari plat hitam yang diposisikan di atas rak pengering dilengkapi kisi-kisi pengatur aliran udara pada setiap rak juga telah dikembangkan [7].

Pengering tipe ERK umumnya memiliki kolektor surya yang berfungsi sebagai perangkap panas. Kolektor surya bekerja dengan menyerap dan mengumpulkan radiasi matahari yang melewati tutup transparan oleh absorber dan dikonversi menjadi panas. Absorber dapat dibuat dari plat berbahan seng atau aluminium yang dicat berwarna hitam berbentuk datar atau bergelombang. Kolektor surya dapat dipasang pada ruang pengering atau terpisah dari ruang pengering. Pemasangan langsung pada ruang pengering dapat menghemat tempat dan biaya pembuatan menjadi lebih murah, sedangkan dengan pemasangan kolektor surya secara terpisah dapat menangkap panas lebih optimal.

Kolektor surya statis dapat dibedakan menjadi tipe kolektor plat datar, kolektor terkonsentrasi (parabola) dan kolektor pipa (evacuated tube collectors) [8]. Kolektor plat datar merupakan kolektor surya yang paling banyak digunakan karena bentuknya sederhana, mudah dibuat dan ekonomis. Kolektor tipe ini dapat memanaskan air hinga mencapai temperatur antara $30^{\circ} \mathrm{C}$ sampai $80^{\circ} \mathrm{C}$ tergantung dari besarnya radiasi matahari.

Tangkapan radiasi matahari pada kolektor surya dapat lebih dioptimalkan dengan menambahkan media penyimpan panas. Media penyimpan panas berperan untuk mengurangi fluktuasi temperatur dalam ruang pengering, mengurangi kelebihan temperatur dan menyimpan panas agar proses pengeringan tetap dapat berlangsung walaupun panas dari matahari sudah tidak ada lagi.

Penelitian ini menganalisis penggunaan batu serpih sebagai media penyimpan panas. Batu serpih adalah salah satu jenis batuan sedimen yang terdiri dari butiran-butiran halus. Batu serpih biasanya lunak sehingga mudah digores, namun mempunyai struktur yang kompak sehinga tidak mudah terpisah ketika bereaksi dengan air atau komponen lain. Batu Serpih mempunyai permukaan yang halus dan licin pada bagian retakannya. Batu serpih memiliki ciri khas yaitu lunak, baunya seperti tanah liat, butiran yang sangat halus.

Batu serpih (shale) disebut juga batu lanau atau argilit. Batu serpih didefinisikan sebagai jenis batuan sedimen yang tersusun dari mineral utama berukuran halus atau lempung yakni berupa illite, smektit dan kaolinit, serta mineral dengan butiran berat seperti oksida besi, kuarsa, karbonat, mineral sulfida, feldspar dan bahan organik lainnya. Komposisi mineral- mineral tersebut tergantung pada lingkungan tempat terjadinya proses sedimentasi atau pengendapan.

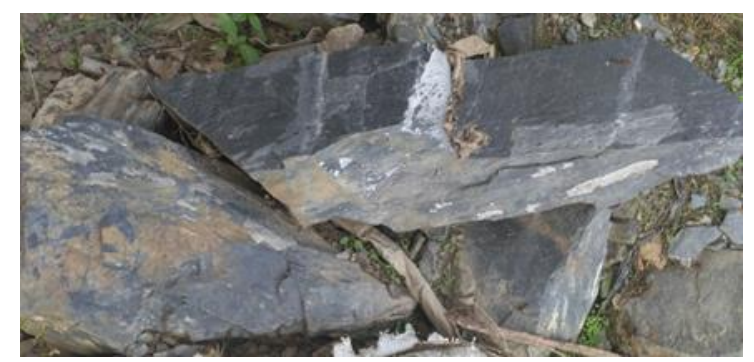

Gambar 1. Batu serpih sebagai media penyimpan panas

\section{METODE PENELITIAN}

\section{Desain Kolektor Surya}

Kolektor surya didesain berdimensi 100 x 150 × $15 \mathrm{~cm}$ dengan komponen meliputi kaca, pelat absorber, styrofoam dan multiplek. Alat dan bahan uji yang digunakan adalah thermokopel, solarimeter, anemometer, jam digital, batu serpih dan kolektor surya. 


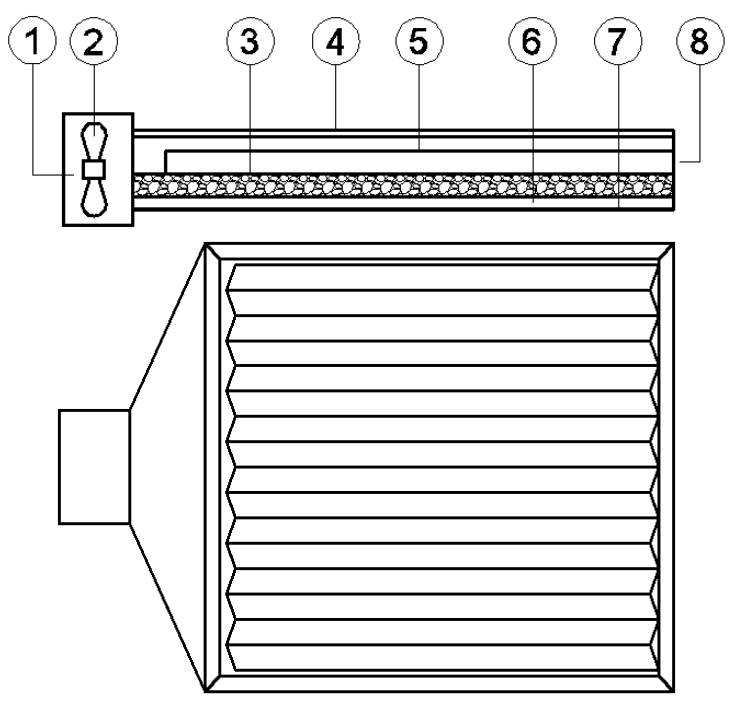

Gambar 2. Desain bentuk kolektor surya

Keterangan :

1. Saluran udara panas

2. Kipas

3. Batu serpih

4. Kaca

5. Pelat absorber

6. Steryfoam

7. Multiplek

8. Saluran udara dingin

Prosedur pengujian dilakukan dengan merancang bangun kolektor surya. Variabel bebas (independent variable) yang digunakan dalam penelitian meliputi kecepatan aliran udara keluar dari kolektor surya dan penggunaan media penyimpan panas. Variabel tak bebas (dependent variable) meliputi suhu udara luar, suhu udara dalam kolektor surya dan suhu udara keluar dari kolektor surya.

Pengujian media penyimpan panas pada kolektor surya dilakukan menggunakan 2 perlakuan yaitu menggunakan media dan tanpa media. Kecepatan aliran fluida yang keluar dari kolektor surya divariasikan menjadi 3 perlakuan. Pengambilan data dimulai dari pukul 08.00 sampai pukul 16.00 dengan selang waktu pengambilan data adalah setiap 30 menit. Pengambilan data untuk setiap kombinasi perlakuan dilakukan dengan pengulangan sebanyak 3 kali.

Persentase kenaikan performansi kolektor surya dengan media penyimpan panas berupa batu serpih pada ruang kolektor surya dapat dihitung sebagai berikut :

$$
\mathrm{PP}=\frac{T 2 \text { in }-T 1 \mathrm{in}}{T 1 \mathrm{in}}
$$

Persentase kenaikan performansi kolektor surya dengan media penyimpan panas berupa batu serpih pada saluran keluar kolektor surya

$$
\text { PP }=\frac{T 2 \text { out }-T 1 \text { out }}{\text { T1 out }}
$$

\section{HASIL DAN PEMBAHASAN}

\section{Pembuatan Kolektor Surya}

Tahapan dalam pembuatan kolektor surya meliputi pembuatan rangka kolektor, pemasangan multiplek sebagai dinding kolektor, pemasangan steryfoam sebagai penghambat panas, pembuatan pelat kolektor panas, pemasangan kaca dan pemasangan kipas.

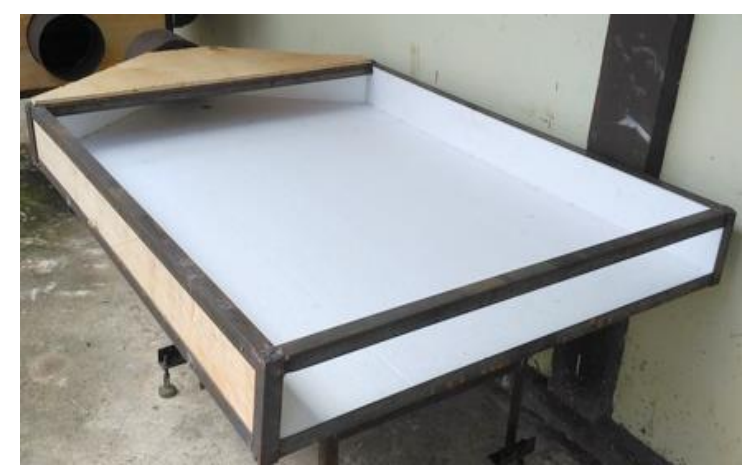

Gambar 3. Kolektor surya hasil rancang bangun

Saluran keluar udara pada kolektor berbentuk silinder berlubang yang dibentuk dari plat dengan ukuran diameter $15 \mathrm{~cm}$ dan tinggi $20 \mathrm{~cm}$. Pelat kolektor surya terbuat dari bahan aluminium yang dicat hitam dan dibentuk bergelombang. 

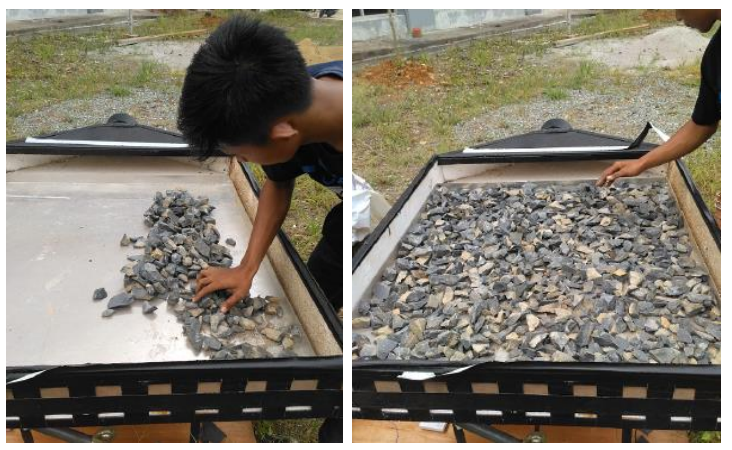

Gambar 4. Penggunaan batu serpih sebagai media penyimpan panas

Media penyimpanan panas yang digunakan dalam penelitian ini adalah batu serpih. Ukuran batu serpih yang digunakan sebagai media penyimpan panas berukuran rata-rata $2 \times 3 \mathrm{~cm}$. Bagian atas batu serpih diletakkan pelat perangkap panas yang telah dicat hitam. Volume batu serpih yang digunakan pada kolektor surya adalah $0,036 \mathrm{~m}^{3}$.

\section{Uji Kinerja Kolektor Surya}

Uji kinerja dilakukan menggunakan 2 buah kolektor surya yang dibuat dengan ukuran dan bahan yang sama. Salah satu kolektor surya ditambahkan batu serpih sebagai media penyimpan panas sedangkan yang lainnya tanpa media penyimpan panas. Data hasil pengujian dikumpulkan dalam waktu yang sama pada kolektor surya yang berbeda. Hasil pengujian kemudian dicatat dan dianalisis untuk mengetahui kinerja kolektor surya yang dirancang bangun.

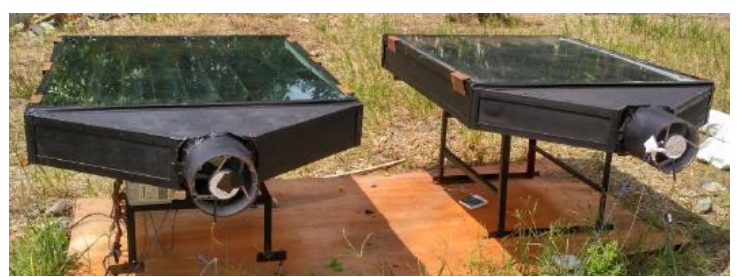

Gambar 5. Uji kinerja kolektor surya dengan batu serpih sebagai media penyimpan panas

Persentase kenaikan performansi kolektor surya dengan media penyimpan panas berupa batu serpih dibanding kolektor surya tanpa media penyimpan panas dapat dihitung dengan persamaan 1 dan 2. Hasil perhitungan persentase kenaikan performansi kolektor surya dapat dilihat sebagai berikut :

1. Persentase kenaikan performansi (PP) kolektor surya dengan media penyimpan panas batu serpih pada ruang kolektor surya

$$
\begin{aligned}
\mathrm{PP} & =\frac{T 2 i n-T 1 i n}{T 1 i n} \\
& =\frac{45,55-43,83}{43,83}=3,92 \%
\end{aligned}
$$

2. Persentase kenaikan performansi (PP) kolektor surya dengan media penyimpan panas berupa batu serpih pada saluran keluar kolektor surya

$$
\begin{aligned}
\text { PP } & =\frac{T 2 \text { out }-T 1 \text { out }}{T 1 \text { out }} \\
& =\frac{48,14-46,01}{46,01}=4,63 \%
\end{aligned}
$$

\section{Temperatur pada ruang dan saluran keluar kolektor surya}

Rata-rata temperatur pada ruang kolektor surya dan saluran keluar kolektor dengan media penyimpan panas adalah $45,55^{\circ} \mathrm{C}$ dan $48,14^{\circ} \mathrm{C}$, sedangkan rata-rata temperatur pada ruang kolektor surya dan saluran keluar kolektor tanpa media penyimpan panas adalah $43,83^{\circ} \mathrm{C}$ dan $46,01^{\circ} \mathrm{C}$. Hasil ini menunjukkan bahwa penambahan media penyimpan panas berupa batu serpih dapat meningkatkan rata-rata temperatur sebesar $1,72{ }^{\circ} \mathrm{C}$ pada ruang kolektor surya dan $2,14{ }^{\circ} \mathrm{C}$ pada saluran keluar kolektor.

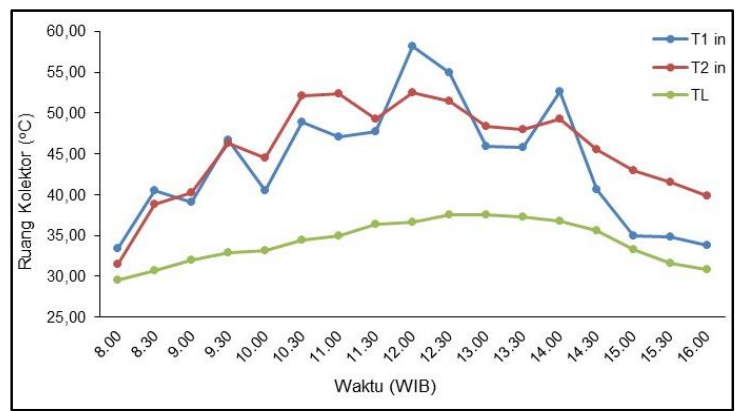

Gambar 6. Rata-rata temperatur ruang perangkap panas hasil uji kinerja 


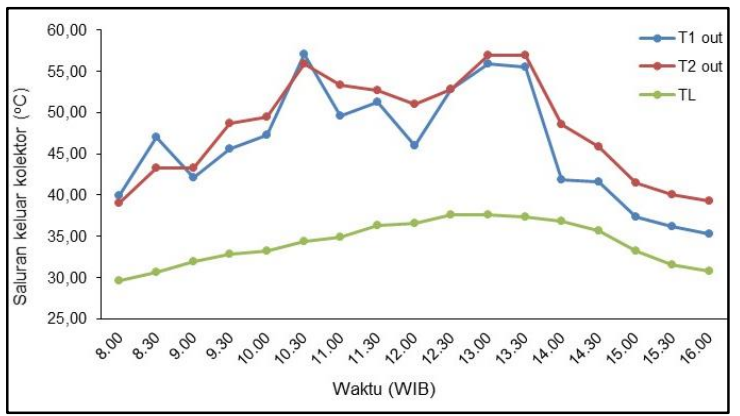

Gambar 7. Rata-rata temperatur saluran keluar kolektor hasil uji kinerja

Keterangan gambar :

$\mathrm{T} 1$ in $=$ Temperatur ruang kolektor tanpa media penyimpan panas

$\mathrm{T} 2$ in $=$ Temperatur ruang kolektor dengan media penyimpan panas

T1 out $=$ Temperatur saluran keluar kolektor tanpa media penyimpan panas

T2 out $=$ Temperatur saluran keluar kolektor dengan media penyimpan panas

$\mathrm{TL}=$ Temperatur lingkungan

Grafik hasil pengujian juga menunjukkan bahwa temperatur pada ruang kolektor surya dan saluran keluar kolektor lebih stabil pada saat terjadi penurunan radiasi matahari. Pada kondisi awal proses pengeringan, pukul 08.00-08.30 WIB temperatur pada ruang kolektor surya dengan media penyimpan panas lebih rendah dibanding tanpa media penyimpan panas, karena kalor pada kolektor surya sebagian digunakan untuk memanaskan batu serpih. Pada sore hari, pukul 14.30 16.00 WIB temperatur pada ruang kolektor surya dengan media penyimpan panas lebih tinggi dan relatif stabil dibanding tanpa media penyimpan panas, karena sebagian kalor masih tersimpan pada batu serpih yang digunakan untuk membantu meningkatkan temperatur pada kolektor surya.

\section{Temperatur pada kecepatan aliran udara $6 \mathrm{~m} / \mathrm{s}$}

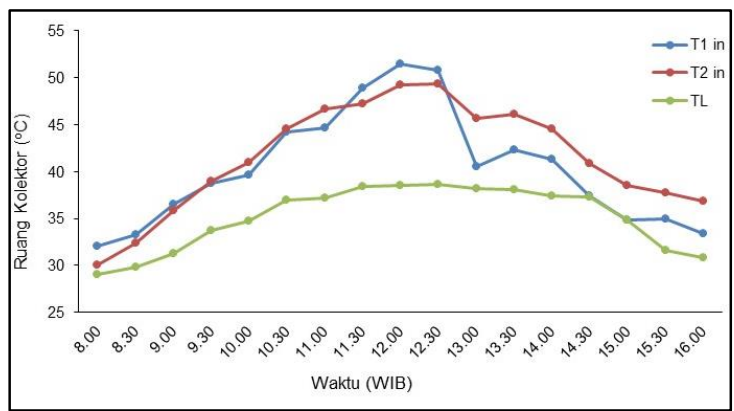

Gambar 8. Temperatur ruang kolektor pada kecepatan aliran udara $6 \mathrm{~m} / \mathrm{s}$

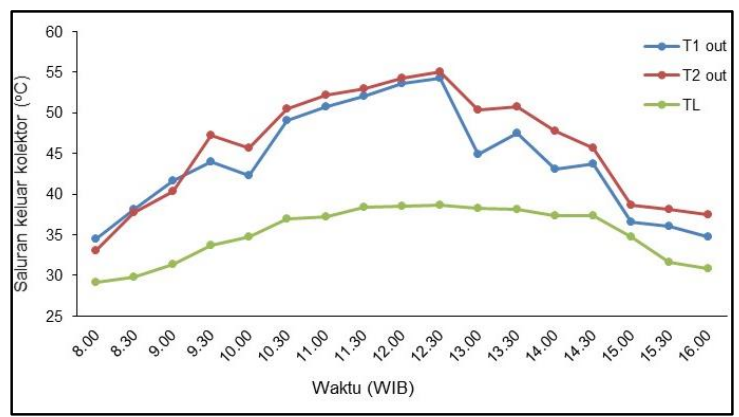

Gambar 9. Temperatur saluran keluar kolektor pada kecepatan aliran udara $6 \mathrm{~m} / \mathrm{s}$

Rata-rata temperatur dalam ruang kolektor surya dengan media penyimpan panas pada kecepatan aliran udara $6 \mathrm{~m} / \mathrm{s}$ diperoleh sebesar $41,51^{\circ} \mathrm{C}$, sedangkan tanpa media penyimpan panas sebesar $40,31^{\circ} \mathrm{C}$ dengan temperatur lingkungan $35,09^{\circ} \mathrm{C}$. Terjadi peningkatan temperatur udara yang dihasilkan pada ruang kolektor surya dengan media penyimpan panas sebesar $1,20^{\circ} \mathrm{C}$. Rata-rata temperatur saluran keluar kolektor dengan media penyimpan panas pada kecepatan aliran udara $6 \mathrm{~m} / \mathrm{s}$ diperoleh sebesar $45,77^{\circ} \mathrm{C}$, sedangkan tanpa media penyimpan panas sebesar $43,93^{\circ} \mathrm{C}$. Perbedaan temperatur yang dihasilkan pada saluran keluar kolektor surya yaitu sebesar $1,84^{\circ} \mathrm{C}$.

\section{Temperatur pada kecepatan aliran udara $4 \mathrm{~m} / \mathrm{s}$}

Rata-rata temperatur dalam ruang kolektor dengan media penyimpan panas pada kecepatan aliran udara $4 \mathrm{~m} / \mathrm{s}$ diperoleh sebesar $47,09^{\circ} \mathrm{C}$, sedangkan kolektor tanpa media penyimpan panas sebesar $45,16^{\circ} \mathrm{C}$ dengan temperatur lingkungan $33,9^{\circ} \mathrm{C}$. 
Pada kondisi ini, temperatur pada saluran keluar kolektor juga mengalami peningkatan sebesar $2,01^{\circ} \mathrm{C}$, dengan media penyimpan panas diperoleh sebesar $48,73^{\circ} \mathrm{C}$, sedangkan kolektor tanpa media penyimpan panas sebesar $46,72^{\circ} \mathrm{C}$.

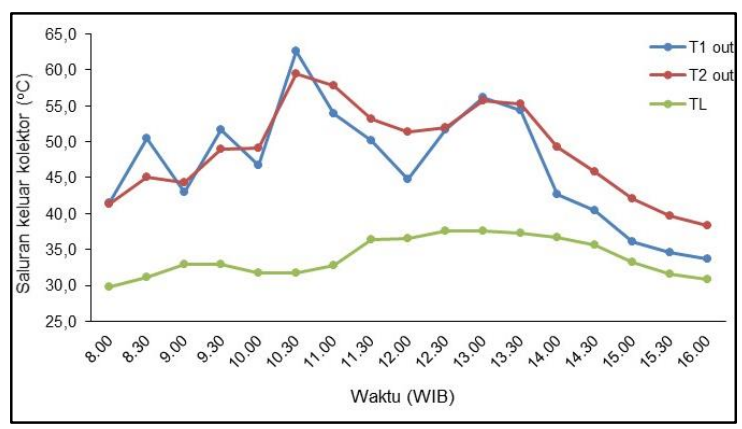

Gambar 10. Temperatur ruang kolektor pada kecepatan aliran udara $4 \mathrm{~m} / \mathrm{s}$

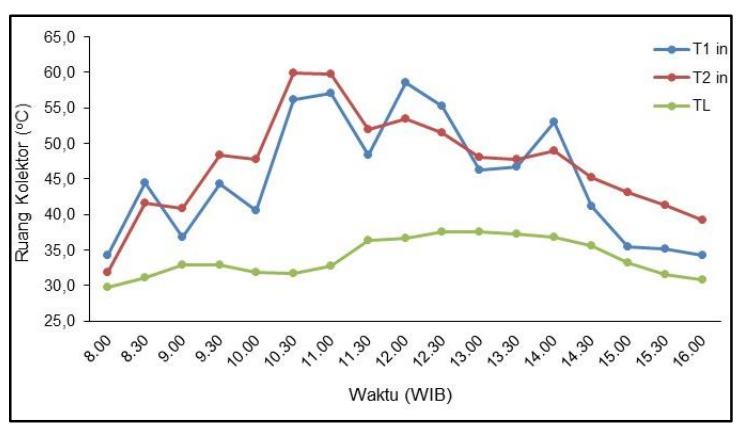

Gambar 11. Temperatur saluran keluar kolektor pada kecepatan aliran udara $4 \mathrm{~m} / \mathrm{s}$

\section{Temperatur pada kecepatan aliran udara $2 \mathrm{~m} / \mathrm{s}$}

Rata-rata temperatur dalam ruang kolektor dengan media penyimpan panas pada kecepatan aliran udara $2 \mathrm{~m} / \mathrm{s}$ diperoleh sebesar $48,05^{\circ} \mathrm{C}$, sedangkan kolektor surya tanpa media penyimpan panas sebesar $46,03^{\circ} \mathrm{C}$ dengan temperatur lingkungan $33,51^{\circ} \mathrm{C}$. Terjadi peningkatan temperatur udara yang dihasilkan pada ruang kolektor surya dengan media penyimpan panas sebesar $2,02^{\circ} \mathrm{C}$. Rata-rata temperatur saluran keluar kolektor surya dengan media penyimpan panas pada kecepatan aliran udara $2 \mathrm{~m} / \mathrm{s}$ diperoleh sebesar $49,93^{\circ} \mathrm{C}$, sedangkan kolektor surya tanpa media penyimpan panas sebesar $47,37^{\circ} \mathrm{C}$. Perbedaan temperatur yang dihasilkan pada saluran keluar kolektor surya yaitu sebesar $2,56^{\circ} \mathrm{C}$.

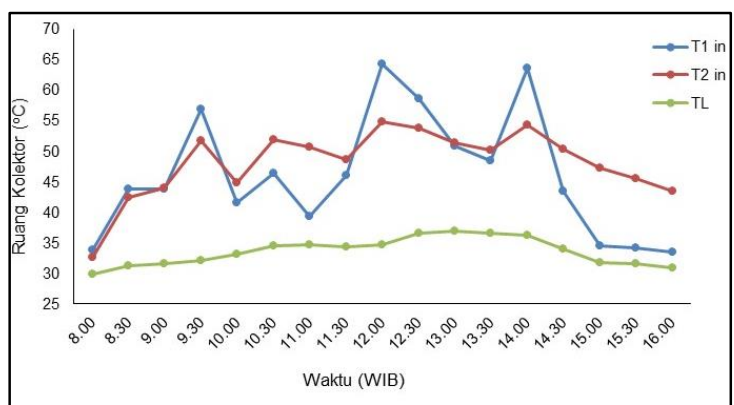

Gambar 12. Temperatur ruang kolektor pada kecepatan aliran udara $2 \mathrm{~m} / \mathrm{s}$

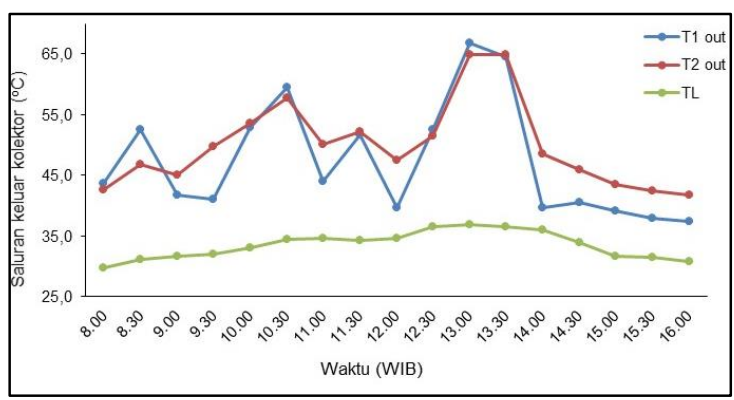

Gambar 13. Temperatur saluran keluar kolektor pada kecepatan aliran udara $2 \mathrm{~m} / \mathrm{s}$

Hasil pengujian menunjukkan bahwa temperatur pada ruang kolektor surya dan saluran keluar kolektor yang menggunakan media penyimpan panas relatif lebih stabil pada saat terjadi penurunan radiasi matahari.

Kecepatan udara pada saluran keluar kolektor mempengaruhi temperatur dalam ruang dan saluran keluar kolektor surya. Semakin cepat aliran udara keluar dari saluran keluar kolektor maka temperatur udara panas dalam ruang dan saluran keluar kolektor surya semakin rendah. Hasil pengujian mendapatkan temperatur tertinggi dalam ruang dan saluran keluar kolektor masing-masing sebesar $48,05^{\circ} \mathrm{C}$ dan $49,93^{\circ} \mathrm{C}$ saat kecepatan udara mengalir pada saluran keluar kolektor sebesar $2 \mathrm{~m} / \mathrm{s}$

\section{KESIMPULAN}

Berdasarkan hasil uji kinerja yang telah dilakukan dapat dibuat beberapa kesimpulan sebagai berikut :

1. Kolektor surya dengan media penyimpan panas berupa batu serpih hasil rancang bangun dapat berfungsi dengan baik dalam menyimpan dan mendistribusikan udara panas dari 
kolektor surya menuju saluran keluar kolektor.

2. Kolektor surya dengan tambahan media penyimpan panas berupa batu serpih dapat meningkatkan performansi kolektor sebesar 3,92\% pada ruang kolektor surya, dan sebesar 4,63\% pada saluran keluar kolektor surya.

3. Hasil pengujian menunjukkan bahwa temperatur pada ruang kolektor surya dan saluran keluar kolektor lebih stabil pada saat terjadi penurunan radiasi matahari terutama pada sore hari.

4. Kecepatan udara pada saluran keluar kolektor mempengaruhi temperatur dalam ruang dan saluran keluar kolektor surya. Semakin cepat aliran udara keluar dari saluran keluar kolektor maka temperatur udara panas dalam ruang dan saluran keluar kolektor surya semakin rendah.

\section{REFERENSI}

[1]. Prasad, J, Vijay, VK, Tiwari, GN, Sorayan, VPS. 2006. Study on performance evaluation of hybrid drier for tumeric (Curcuma longa L.) drying at village scale. Journal of Food Engineering. 75(4):497-502.

[2]. Nitipraja, F. A., 2008, Rancangan Alat Pengering Dengan Kolektor Surya Pelat Datar Yang Menggunakan Air Sebagai Media Penyimpan Panas Untuk Pengeringan Gabah, Departemen Teknik Pertanian, Fakultas Teknologi Pertanian, Institut Pertanian Bogor.

[3]. Noor M.F., 2013, Analisa Penggunaan Bahan Penyimpan Panas Pada Kolektor Alat Pengering Benih Energi Surya, Jurnal Turbo Vol. 2 N0. 2, Hal. 1316
[4]. Astawa K., Tista S.P.G., Saputra I.W.H., 2014, Analisis Performansi Kolektor Surya Pelat Datar dengan Media Penyimpan Panas Pasir untuk Pemanas Udara, Jurnal Teknika (Jurnal Ilmiah Teknik), Vol. 10, No. 1, Hal. 43 - 50 .

[5]. Mustaqimah, 2016, Penggunaan Kendal Sebagai Media Penyimpan Panas pada Kolektor Surya Plat Datar, Jurnal Rona Teknik Pertanian, Vol. 9 No. 2, Oktober 2016, Hal. 106 115.

[6]. Abdullah, K., Wulandani, D., Wenu, F., dan Agustina, SE., 1994, Optimasi dalam Perencanaan Alat Pengering Hasil Pertanian dengan Energi Surya [laporan akhir penelitian hibah bersaing I]. Bogor (ID): Ditjen Dikti, Departemen Pendidikan dan Kebudayaan IPB.

[7]. Nelwan L.O. 1997. Pengeringan Kakao dengan Energi Surya Menggunakan Rak Pengering dengan Kolektor Tipe Efek Rumah Kaca. Tesis. Program Pasca Sarjana. IPB Bogor.

[8]. Kalogirou, S., 2009, Solar Energy Engineering : Processes And Systems, Elsevier, United States of America. 